Pobrane z czasopisma Studia Bia?orutenistyczne http://bialorutenistyka.umcs.pl Data: 26/04/2023 11:17:47

DOI:10.17951/sb.2021.15.11-31

Studia Białorutenistyczne 15/2021 HISTORY, CULTURE AND SOCIOLOGY

ISSN: 1898-0457 e-ISSN: 2449-8270

Licence: CC BY 4.0

\title{
Mirosław Jankowiak
}

The Czech Academy of Sciences, Praga (Czech Republic)

e-mail: jankowiak@slu.cas.cz

https://orcid.org/0000-0001-6212-1463

\section{Prasa białoruska międzywojennej Łotwy (przegląd wydawnictw)*}

Belarusian Press of Interwar Latvia. Review of Publications

Беларуская прэса міжваеннай Латвіі. Агляд выданняў

\begin{abstract}
The presented article describes the Belarusian press that was published in Latvia in the interwar period (1920-1933). The available publications usually only mention that Belarusianlanguage newspapers were published in Riga or Daugavpils, were mentioned by name, provided general information, or analysed a specific aspect (the language of the texts or some issue raised in the press). The author's intention is to provide a broader description of each of the printed newspapers with the fullest possible information about their editorial office, authors, subject matter, or place of publication. The second important issue was to show the political, social, and cultural conditions that influenced the functioning of the Belarusian minority in Latvia and, inter alia, creating new newspapers in Belarusian and publishing them. For this purpose, the author conducted a library query in Riga (The National Library of Latvia), in London (Francis Skaryna Belarusian Library and Museum) and in Prague (Slavonic Library of the National Library in the Czech Republic). The creation of new newspapers and the frequency of their appearances depended primarily on the finances of Belarusian organizations and their activity as well as current political events (such as the so-called "Belarusian trial" and the introduction of authoritarian rule by K. Ulmanis in 1934). The most important were the newspapers edited by the most active activists (K. Jezavitaŭ and S. Sakharaŭ) and published by the largest Belarusian organizations (newspapers: Голас беларуса, Беларуская школа ў Лавтвіi and Школьная праца). Most of the newspapers were published irregularly and/or only one or a few issues were published.
\end{abstract}

* Autor wykazuje podziękowanie dr hab. Jerzemu Grzybowskiemu z Uniwersytetu Warszawskiego oraz Jūliji Gabranovej z Rygi za udostępnienie części numerów gazet, które nie znajdowały się w archiwum autora, oraz za cenne wskazówki i informacje. 
Keywords: Belarusians in Latvia, Belarusian press in Latvia, Belarusian language, K. Jezavitaŭ, S. Sacharaŭ

\begin{abstract}
Abstrakt
W prezentowanym artykule omówiono prasę białoruską, wydawaną na Łotwie w okresie międzywojennym (w latach 1920-1933). W dostępnych publikacjach zazwyczaj odnajdujemy jedynie wzmianki o tym, że gazety i periodyki białoruskojęzyczne wychodziły w Rydze czy Dyneburgu, wymienia się je z nazwy, dając ogólną informację, albo analizuje konkretny aspekt (język tekstów czy wybrane zagadnienie poruszane na łamach prasy). Zamierzeniem autora była prezentacja szerszego opisu każdego z drukowanych wydań, z możliwie jak najpełniejszą informacją o jego redakcji, autorach, tematyce czy miejscu wydawania. Drugim ważnym zagadnieniem było ukazanie uwarunkowań polityczno-społeczno-kulturalnych, które wpływały na funkcjonowanie mniejszości białoruskiej na Łotwie i m. in. tworzenie nowych gazet i wydań periodycznych w języku białoruskim oraz ich druk. Autor przeprowadził w tym celu kwerendę biblioteczną w Rydze (Biblioteka Narodowa Łotwy), w Londynie (Białoruska Biblioteka i Muzeum im. Franciszka Skaryny) oraz w Pradze (Biblioteka Słowiańska Biblioteki Narodowej w Czechach). Powoływanie nowych gazet i periodyków, częstotliwość ich wychodzenia uzależnione były przede wszystkim od możliwości finansowych białoruskich organizacji i ich aktywności a także bieżących wydarzeń politycznych (jak np. tzw. „Białoruski proces” czy wprowadzenie w 1934 r. rządów autorytarnych K. Ulmanisa). Największe znaczenie odegrała prasa, której redaktorami byli najbardziej aktywni działacze (m.in. K. Jezawitau i S. Sacharau), a które wydawane były przez największe organizacje białoruskie (np.: Голас беларуса, Беларуская школа ў Латвіi oraz Школьная праца). Większość prasy wychodziło nieregularnie i/lub tylko w jednym lub kilku numerach.
\end{abstract}

Słowa kluczowe: Białorusini na Łotwie, prasa białoruska na Łotwie, okres międzywojenny, język białoruski, K. Jezawitau, S. Sacharau

\title{
Анатацыя
}

У артыкуле аналізуецца беларуская прэса, якая выходзіла ў Латвіі ў міжваенны перыяд (1920-1933 гг.). У даступных публікацыях пераважна толькі ўзгадваецца, што беларускамоўныя перыядычныя выданні друкаваліся ў Рызе і Даўгаўпілсе, пералічваюцца ix назвы, падаецца агульная інфармацыя або аналізуецца канкрэтны аспект (напрыклад, мова тэкстаў або выбраная тэматыка, якая закраналася ў друкаваных там артыкулах). Мэта аўтара - стварыць разгорнутую характарыстыку перыядычных выданняў, даць, па магчымасці, падрабязную інфармацыю пра рэдакцыю, аўтараў, тэматыку і месца друку. Другі важны аспект публікацыі - паказаць палітычныя і грамадска-культурныя перадумовы, якія мелі ўплыў на функцыянаванне беларускай меншасці ў Латвіі і, паміж іншымі, выданне новых газет на беларускай мове, а таксама іх друк. 3 мэтай сабраць усю беларускамоўную прэсу аўтар працаваў у Нацыянальнай бібліятэцы Латвіі ў Рызе, Бібліятэцы і Музеі імя Францішка Скарыны ў Лондане, а таксама Славянскай бібліятэцы Нацыянальнай бібліятэкі Чэхіі. Стварэнне новых перыядычных выданняў і частотнасць ix друку залежыла, перад усім, ад наяўных матэрыяльных сродкаў і актыўнасці беларускій арганізацый, а таксама ад актуальных палітычных падзеяў (як, напрыклад, т.зв. 
„Беларускі працэс” або ўвядзенне аўтарытарнага рэжыму К. Улманісам у 1934 г.). Вялікае значэнне мелі перыядычныя выданні, якіх рэдактарамі былі найбольш актыўныя грамадскія дзеячы (напр. К. Езавітаў, С. Сахараў), і якія выдаваліся беларускімі арганізацыямі 3 колькаснай перавагай (напр.: „Голас беларуса”, „Беларуская школа ў Латвіi” і „Школьная праца"). Большая частка газет друкавалася нерэгулярна i/або абмяжоўвалася адным або некалькімі нумарамі.

Ключавыя словы: Беларусы Латвіі, беларуская прэса ў Латвіі, міжваенны перыяд, беларуская мова, К. Езавітаў, С. Сахараў

\section{Wprowadzenie}

Zmiany po I wojnie światowej zmieniły nie tylko układ granic w Europie, ale umożliwiły wielu narodom stworzenie własnego państwa. Inaczej sytuacja wyglądała w przypadku Białorusinów. W wyniku traktatu ryskiego ziemie białoruskie zostały podzielone pomiędzy Polskę i Białoruską SRR (wchodzącą w skład ZSRR). Białorusini znaleźli się nie tylko w Związku Sowieckim, ale i w kilku nowo powstałych krajach - Polsce, Litwie, Łotwie czy Estonii. Jednym z najważniejszych aspektów działalności białoruskiej emigracji było utrzymanie oraz kształtowanie tożsamości narodowej. Bardzo ważną rolę odgrywało tworzenie szkół oraz wydawanie prasy. Takie procesy miały też miejsce na Łotwie, szczególnie w sprzyjających mniejszościom narodowym latom 20. XX w.

Realna działalność polityczno-społeczna Białorusinów na Łotwie rozpoczęła się dopiero w latach 1919-1920, kiedy to w Rydze działała misja dyplomatyczna Białoruskiej Republiki Ludowej i konsulat, a w Lipawie - drugi konsulat. Na początku 1920 r. Białorusini zaczęli organizować swoje życie kulturalno-oświatowe (Jekabsons, 2004, s. 77). Okres międzywojenny (szczególnie lata 20. - do roku 1934) był w całej historii Białorusinów na Łotwie niewątpliwie najlepszy - wtedy to powstawały liczne szkoły, organizacje społeczno-kulturalne, gazety i czasopisma, teatr, prowadzono kursy dla nauczycieli szkół białoruskich itd. (więcej por. Jankowiak, 2008; Golubeva, 2010, s. 194-198; Apine, 2017; Jekabsons, 2017; Jankowiak, 2019 i in.). Kulturalno-społecznej działalności łotewskich Białorusinów sprzyjał między innymi Jānis Rainis, łotewski pisarz, w latach 1926-1928 pełniący funkcję ministra oświaty (więcej o związkach Rainisa z Białorusinami - zob. Cīrule, 2017). Sytuacja zmieniła się w roku 1934 wraz z przewrotem politycznym Kārlisa Ulmanisa, który ogłosił stan wojenny, rozwiązał sejm i wszystkie partie polityczne, a w 1936 r. objął funkcję prezydenta Łotwy. Był to okres wzmożonej lettyzacji kraju, kiedy systematycznie zamykano organizacje mniejszości narodowych i znacząco ograniczano możliwość ich funkcjonowania. Ówczesna polityka władz łotewskich dotknęła wszystkie mniejszości narodowe.

Temat prasy białoruskiej na emigracji oraz jej roli w kształtowaniu i podtrzymywaniu białoruskiej tożsamości narodowej, kultury i języka białoruskiego był poruszany w licznych publikacjach. Warto tutaj wspomnieć kilka z nich, jak np. monografię 
Niny Barszczewskiej pt. Беларуская эміграцыя - абаронца роднае мовы ${ }^{1}$, w której badaczka opisała prasę białoruską, funkcjonującą w Polsce, na Litwie czy w Niemczech (autorka tylko wspomina o prasie białoruskiej na Łotwie) (Barszczewska, 2004, s. 240-248, 265-270, 297-300).

Językiem prasy białoruskiej wydawanej na Łotwie zajmuje się obecnie Jūlija Grabranova z Łotwy, która napisała rozprawę doktorska pt. Baltkrievu un latviešu valodas kontakti 20. gadsimta pirmajā pusē in mūsdnienās ${ }^{2}$ (Gabranova 2016a, s. 133-140; Gabranova 2016b, s. 28-33). Białoruska badaczka jest również autorką artykułu Периодические издания на белорусском языке, изданные в период Первой Латвийской Республики (1920-1930)³. W swojej publikacji autorka wyliczyła białoruskie publikacje z obszaru Łotwy, ale więcej miejsca poświęciła tylko gazecie Hołas biełarusa (omówiła tematykę artykułów i język).

Zagadnienie to nie było jednak szerzej poruszane w publikacjach naukowych, np. w książce Latvijas republikas prese 1918-19404 autorzy omówili prasę niemiecką, rosyjską, żydowską, polską oraz litewską, podczas gdy białoruską pominięto (Treijs, 1996). O białoruskich wydaniach zazwyczaj wspomina się krótko, bez szerszego omówienia, podając tytuł, lata wydawania czy redaktora (por. Golubeva, 2010, s. 194-198; Gabranova 2016a, s. 133-140; Gabranova, 2016b, s. 133-138; Ageenka, 2017, s. 38-41; Jekabsons, 2018, s. 138-139). W niektórych publikacjach zajmowano się z kolei wybranym zagadnieniem, jak np. artykuł Jerzego Grzybowskiego pt. Савецкая рэчаіснасць на бачынах беларускай газеты ў Латвіi „Голас Беларуса“ (1925-1929 2.) (Gryboǔskì, 2015).

Zamierzeniem autora jest przybliżyć czytelnikowi prasę białoruską, wychodzącą w międzywojennej Łotwie, ukazując jej charakter, skład redakcji, autorów tekstów, format, tematykę i inne interesujące informacje, czyli wszystkie podstawowe informacje. Artykuł ma zatem charakter przeglądu wszystkich periodyków oraz ma za zadanie wprowadzić czytelnika w badane zagadnienie i kolejne publikacje autora, których celem będzie już szczegółowe poruszenie i przeanalizowanie wybranych zagadnień poruszanych w tekstach prasowych. Omawiane poniżej tytuły zachowały się w Bibliotece Narodowej Łotwy (Latvijas Nacionālā Bibliotēka), Bibliotece Narodowej Białorusi (Нацыянальная бібліятэка Беларусі), Bibliotece im. F. Skaryny w Londynie (Беларуская Бібліятэка і Музей імя Францішка Скарыны) oraz Bibliotece Słowiańskiej Biblioteki Narodowej w Czechach (Slovanská knihovna, Národní knihovna České republiky). Przy opisie gazet zachowuję oryginalną pisownię zastosowaną w poszczególnych periodykach.

Pol. Emigracja białoruska - obrońca języka ojczystego.

Pol. Białorusko-łotewskie kontakty językowe w pierwszej połowie wieku XX. i wspótcześnie.

3 Pol. Wydania periodyczne w języku białoruskim, wydane $w$ okresie Pierwszej Republiki Łotewskiej (1920-1930).

4 Pol. Prasa Republiki Łotewskiej 1918-1940. 


\section{Dzieje Białorusinów na Łotwie (zarys zagadnienia) ${ }^{5}$}

Zrozumienie specyfiki wychodzącej na Łotwie prasy białoruskiej nie jest możliwe bez wprowadzenia czytelnika chociażby w krótki zarys dziejów tej mniejszości. Białorusini zamieszkujący na ziemiach łotewskich są ludnością autochtoniczną a kontakty (potwierdzone historycznymi dokumentami) sięgają średniowiecza, kiedy to najpierw Bałtowie i Krywicze prowadzili ożywioną wymianę handlową wykorzystując rzekę Dźwinę a następnie Wielkie Księstwo Litewskie (głównie miasta Witebsk i Połock) z Zakonem Kawalerów Mieczowych. O znaczeniu tych kontaktów świadczy między innymi fakt, że w Rydze władze miasta utworzyły oddzielny dział dokumentów Moscowitica-Ruthenica opracowywanych w języku ruskim ( $\mathrm{tj}$. umowy z Witebskiem, Połockiem, Smoleńskiem i książętami litewskimi, wiek XIII-XVII). Ożywionym kontaktom sprzyjał też okres wspólnej przynależności ziem do I Rzeczypospolitej.

Zmiany nastąpiły po rozbiorach Rzeczypospolitej, kiedy to ziemie weszły w skład Imperium Rosyjskiego, a dokładniej guberni witebskiej, nazywanej czasem nieoficjalnie „białoruską”. Przemiany gospodarcze, budowa tzw. kolei żelaznej i zniesienie prawa pańszczyźnianego, a także sytuacja ekonomiczna przyczyniły się w II poł. XIX w. do znaczącej migracji ludności z ziem białoruskich na północ (głównie do Łatgalii i Semigalii). W pierwszym spisie carskim z $1897 \mathrm{r}$. liczba ludności pochodzenia białoruskiego dla ziem łotewskich wynosiła 81900 osób (4,3\%), a w pierwszym łotewskim spisie ludności z 1920 r. - 75600 Białorusinów. Ruchy narodowe, które intensywniej działały od czasu rewolucji 1905 r., objęły również białoruską inteligencję na ziemiach łotewskich. Wchodząc w 1918 r. w nową epokę, niepodległej już Łotwy, Białorusini mieli więc długą tradycję związków białorusko-łotewskich i zamieszkiwania tych ziem, a tak wysoka liczba ludności pochodzenia białoruskiego potrzebowała zabezpieczenia funkcjonowania nie tylko na poziomie ekonomicznym, ale także kulturalno-oświatowym. Łotwa lat 20. XX w. była bardzo sprzyjającym mniejszościom narodowym państwem. W krótkim czasie zaczęły powstawać białoruskie szkoły, organizacje, towarzystwa, kółka taneczne i teatr. Ogrom pracy został także włożony w stworzenie białoruskojęzycznej prasy, która zostanie opisana poniżej.

\section{„На чужыне” (1920 r.)}

„Na Czużynie” („Na Obczyźnie”) to pierwszy periodyk Białorusinów Łotwy okresu międzywojennego. W zamyśle redakcji miał to być miesięcznik literacko-społeczny (pełna nazwa brzmiała: „На Чужыне. Літэратурна-грамадзянскі штомесячнік”). W marcu 1920 r. ukazał się pierwszy i zarazem ostatni numer 1/1920, w całości biało-

5 Więcej o historii Białorusinów na Łotwie zob. m.in. (Apine, 1995; Jankowiak, 2009; Hermanis, 2017; Korolëv, 2017).

6 Pol. Na Obczyźnie. Miesięcznik literacko-społeczny. 
ruskojęzyczny, wydany w tzw. taraszkiewicy, liczący 16 czarno-białych stron i cztery kolorowe strony okładki. Redakcja znajdowała się w Rydze przy bulwarze Totlēbena 7 (mieszkanie nr. 3). Redaktorem naczelnym był Hryhor Kaziaczy a wydawcą Oddział Ryski Białoruskiego Towarzystwa Kulturalno-Oświatowego „Baćkaŭszczyna” (Рыжэскі Аддзел Беларускаго Культурна-Прасьветнага Т-ва „Бацькаўшчына”). Pierwszy numer wydrukowano w drukarni E. Levina w Rydze przy ul. Haspodskiej 26. Ówczesna cena numeru wynosiła 5 rubli. Tylko pod jednym artykułem znajduje się nazwisko autora (A. Smolicz). Numer zachował się w Bibliotece Narodowej w Rydze.

W jedynym numerze znalazły się wiersze (J. Kupały i Baćki), opis Białorusinów mieszkających na Łotwie, w Estonii, Finlandii, na Litwie, dział informujący o wydarzeniach w ojczyźnie oraz informacja o białoruskim druku w innych krajach. $\mathrm{Na}$ ostatniej stronie redakcja zamieściła $\mathrm{w}$ formie reklam książki białoruskie wydane przez różne wydawnictwa. W numerze drugim redakcja planowała przybliżyć czytelnikom Białorusinów Francji, Czech, Polski, Ukrainy i Niemiec. Na uwagę zasługuje zamieszczenie mapy na okładce, ukazującej zasięg etnosu białoruskiego. Numer został skonfiskowany przez Ministerstwo Spraw Wewnętrznych Łotwy, a powodem było zamieszczenie mapy Białoruskiej Republiki Ludowej, która obejmowała częściowo ziemie międzywojennej Łotwy - fragmenty powiatu iłuksztańskiego i daugawpilskiego (dyneburskiego). Po reakcji K. Jezawitowa nakład został zwrócony (Jekabsons, 2004, s. 77; Garbanova, 2014, s. 349).

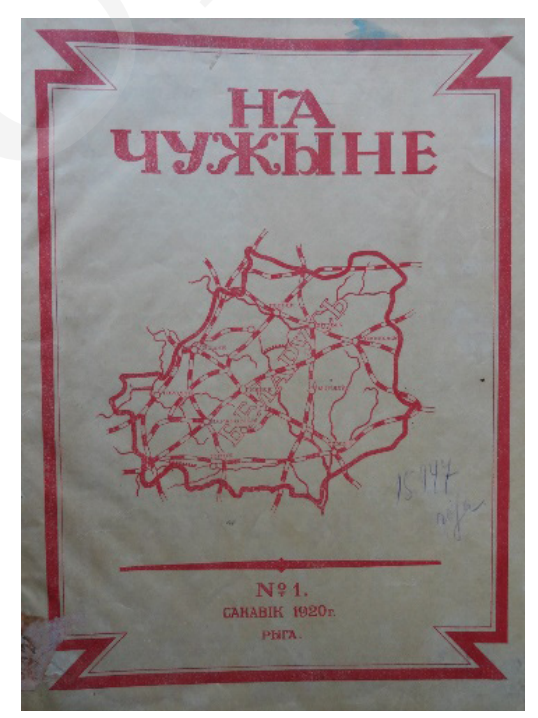

Fot. 1. Strona tytułowa miesięcznika „Na Czużynie”, № 1/1920. 


\section{„Ластаўка” (1923-1924)}

W Białoruskiej Bibliotece im. F. Skaryny w Londynie znajduje się publikacja nosząca nazwę „Ластаўка. Вучнёўская часопіс Люцынскае Беларускае Гімназіi””. Zachował się tylko jeden numer - 4/1923. Ukazały się co najmniej cztery numery. W odróżnieniu od pism takich, jak „Na Czużynie” czy „Hołas Biełarusa”, „Lastaŭka” nie była drukowana, tylko napisana odręcznie, a nakład wynosił 45(?) egzemplarzy ${ }^{8}$. $\mathrm{Z}$ ostatniej strony, na której redakcja zachęca do wsparcia finansowego, dowiadujemy się, że było to pierwsze czasopismo uczniowskie w języku białoruskim wychodzące na Łotwie. W numerze odnajdujemy poezję, prozę, pieśni ludowe, kronikę - łącznie 30 stron. W stopce redaktorskiej zapisano przy redaktorze: kolegium redakcyjne, a przy wydawcy: Sekcja Wydawnicza Kółka Uczniowskiego Gimnazjum Białoruskiego w Lucyniu (Выдавецкая Сэкцыя Вучнёўскага Гуртка Люцынскае Беларускае Гімназіi). Pod tytułem znajdujemy informację, że czasopismo wychodziło za zgodą Ministerstwa Oświaty Łotwy oraz kierownika gimnazjum - K. B. Jezawitowa9 .

Pod tym samym tytułem w $1924 \mathrm{r}$. ukazał się zbiór utworów uczniowskich z lucynskiego gimnazjum białoruskiego (Ластаўка. Зборнік вучнеускіх творау Дзяржаунай Люцынскай Беларускай Гімназіі у Латвіі за 1923-1924 вучэбны год, Выданьне Гімназіі, Люцын 1924), które zachowało się w bibliotekach narodowych w Pradze i Rydze.

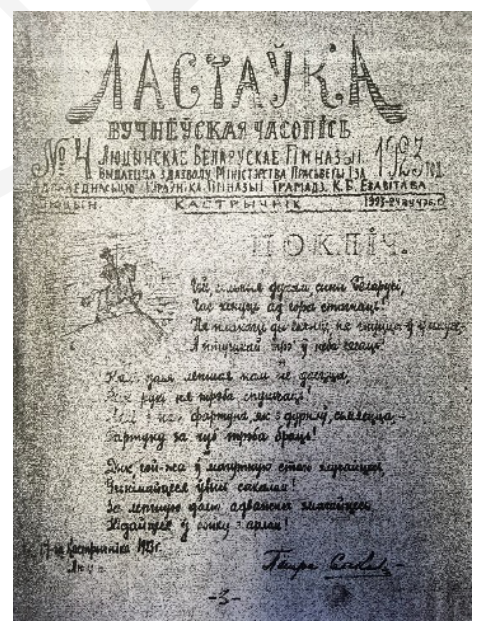

Fot. 2. Czarno-biały skan pierwszej strony czasopisma uczniowskiego „Lastaŭka”, № 4/1923.

Pol. Jaskótka. Czasopismo uczniowskie Białoruskiego Gimnazjum w Lucyniu.

8 Dokładny nakład nie jest czytelny, tylko pierwsza cyfra jest dobrze zapisana (4), a druga nieczytelna (prawdopodobnie 5).

9 Więcej na temat K. Jezawitawa, białoruskiego działacza społeczno-politycznego, wojskowego, pedagoga, i jego działalności na Łotwie, zob. (Gryboǔskì, Jekabsons, 2013; Kazačionok, 2019, s. 31-36). 


\section{„Голас беларуса” (1925-1929)}

Gazeta „Hołas biełarusa”"10 wychodziła w latach 1925-1929, wydano łącznie 61 numerów - najwięcej ze wszystkich periodyków na Łotwie. Czytelnicy mogli go kupować 2-3 razy w miesiącu (w zależności od roku) za 10 ówczesnych santimów. Siedziba redakcji znajdowała się w Rydze przy ul. Marstalı 19, a drukowano ją w typografii E. Levina w Rydze (początkowo ten sam adres co redakcji, potem drukarnia znajdowała się przy ul. Dzirnavu 33). Redakorem naczelnym był K. Jezawitaŭ. Była to gazeta wychodząca w języku białoruskim (tzw. taraszkiewica), sporadycznie pojawiały się teksty po rosyjsku.

$\mathrm{Na}$ łamach artykułów redakcja podejmowała szereg tematów politycznych, gospodarczych, zamieszczano tłumaczenia z języka łotewskiego nowych ustaw czy rozporządzeń rządu, bieżące wydarzenia z Łotwy i zagranicy. Nie brakowało tekstów dotyczących Białorusinów na Łotwie - kwestii narodowych, szkolnictwa białoruskiego na Łotwie. Publikowano także reklamy, twórczość łotewskich Białorusinów (głównie poezję), a także listy do redakcji i komentarze. Sporo miejsca w gazecie poświęcono tzw. procesowi białoruskiemu na Łotwie. ${ }^{11}$

Wśród autorów artykułów można wymienić szereg osób, niektóre podpisywały się nazwiskiem lub pseudonimem. Sporo tekstów napisał sam redaktor naczelny Kanstantyn Jezawitaŭ (publikujący też pod pseudonimem Kastuś, Kastusionak), Siarhiej Sacharaŭ, Wacłaŭ Lastoŭski a także: Szniokawiec, A. Prus, Jurka Harelik, Al. Hałyniec, Dawidowicz, Prażak, K. Barysowicz, Ilowajskij.

W porównaniu z innymi gazetami („Haspadar”, „Biełaruskaja szkoła ŭ Łatwii”), „Hołas biełarusa” był gazetą drukowaną, czarno-białą, o uproszczonej grafice.

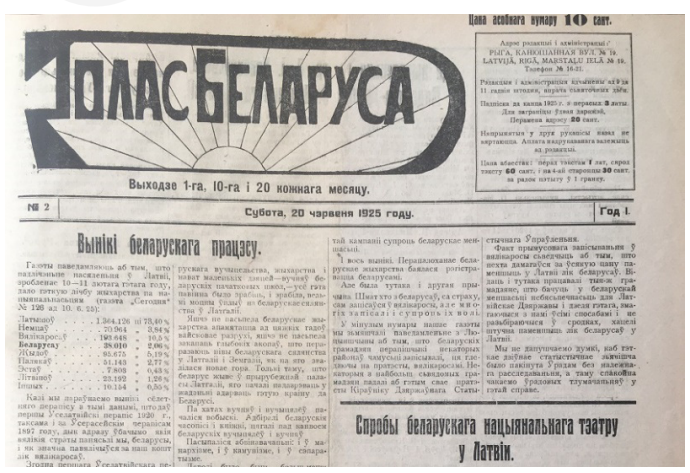

Fot. 3. Fragment strony tytułowej gazety „Hołas biełarusa”, № 2/1925.

10 Pol. Gtos Białorusina.

11 Tzw. proces białoruski dotyczył nauczycieli białoruskich szkół na Łotwie, których władza łotewska oskarżała o działalność antypaństwową i separatystyczną. Miał on miejsce w latach 19241925. Więcej zob. (Kazačënok, 2012). 


\section{„Гаспадар” (1926)}

W Bibliotece Narodowej Łotwy zachowały się do dzisiaj cztery numery (za czerwiec, lipiec, sierpnień oraz wrzesień-listopad 1926 roku). „Haspadar”12 był miesięcznikiem wiejskiej gospodarki i kooperatywu, który wychodził w Rydze w języku białoruskim (tzw. taraszkiewicą). Redakcja miała na początku swoją siedzibę przy ul. Marii 13 (Marijas iela 13), a następnie przy ul. Architeckiej 1 (Arhitektu iela 1). Redaktorem odpowiedzialnym był J. Szczors, a wydawcą Białoruskie Centralne Towarzystwo Pożyczkowo-Oszczędnościowe na Łotwie (Беларускае Цэнтральнае Пазычкова-Зьберагальнае Таварыства ў Латвіi). Haspadar wychodził w środku każdego miesiąca w formacie czarno-białym w drukarni Apta, znajdującej się przy ul. Parkowej 1 (Parku iela 1), a każdy numer miał po 8 stron. Numer kosztował 10 ówczesnych łotewskich santimów.

Czasopismo „Haspadar” poruszało kwestie związane z pracą na roli (np. kalendarz prac polowych, ceny warzyw i owoców, zasady uprawy roli czy budowy budynków gospodarczych), gospodarstwem domowym (np. wyrób wina), edukacją ludności wiejskiej, czy też prowadzeniem sklepu (spożywczego). Ponadto redakcja zamieszczała ogłoszenia oraz prowadziła dział Hołas hramady (z informacjami o bieżącej działalności białoruskich działaczy i organizacji). Wśród autorów tekstów można wyliczyć takie osoby, jak: J. Szczors, N. Lia., A.K., prof. W. Totomianc, N. Pinskaja.

Z graficznego punktu widzenia na szczególną uwagę zasługuje tytuł gazety z rysunkiem przedstawiającym chłopa z koniem i pługiem podczas pracy na tle pola, chaty i zachodzącego (wschodzącego?) słońca.

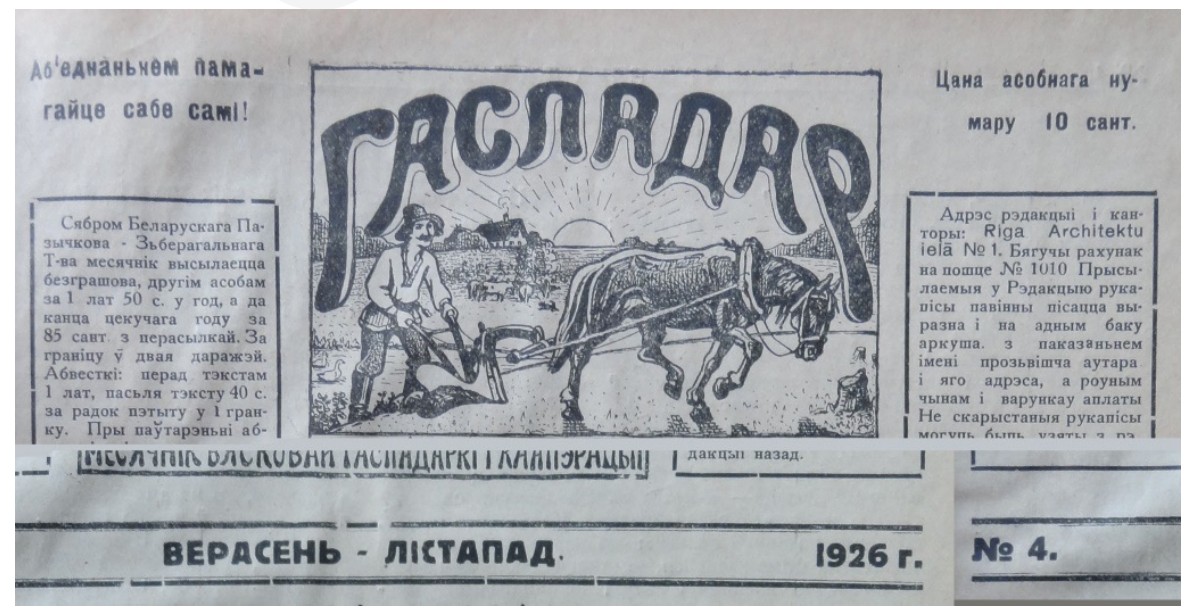

Fot. 4. Górna część strony tytułowej gazety „Haspadar”, № 4/1926.

12 Pol. „Gospodarz”. 


\section{„Школьная праца“ (1926-1929)}

„Szkol'naja praca”"13 wychodziła w Dźwińsku (Daugavpils) nieregularnie, w latach 1926-1929. Łącznie ukazało się 13 numerów - w pierwszym roku siedem numerów, w 1927 trzy, w 1928 i 1929 po dwa. Pełna nazwa brzmiała: „Школьная праца. Часопіс Дзвінскай дзяржаўнай беларускай гімназіi”"14, a wszystkie numery były zapisane odręcznie. Redaktorem naczelnym był S. Sacharaŭ, a redakcja znajdowała się w Dyneburgu przy ul. Warszawskiej 16 (przy gimnazjum białoruskim, które w jednym z numerów zostało przedstawione na okładce).

$\mathrm{Na}$ łamach „Szkol'nej pracy” redakcja zamieszczała wiersze i opowiadania łatgalskich Białorusinów, informacje o bieżącej działalności gimnazjum, kronikę, ogłoszenia, przy czym wiersze i proza były często zdobione rysunkami. Środkowa część czasopisma zazwyczaj miała drukowaną wkładkę ze zdjęciami, ukazującymi życie (np. jubileusze) gimnazjum, zdjęcia trup teatralnych itp. Pisywali do czasopisma: S. Sacharau, A. Bartul, W. Kazłoŭskaja, Piotr Kajraŭ, M. Slogman, M. Racyn, J. Demboŭski, S. Szaŭcoŭ, A. Cichamiraŭ, zamieszczano także wiersze uczniów gimnazjum, np. pod pseudonimami: Kwietka. Numer kosztował 50 santimów (w późniejszych okresach odpowiednio 60 i 80 santimów).
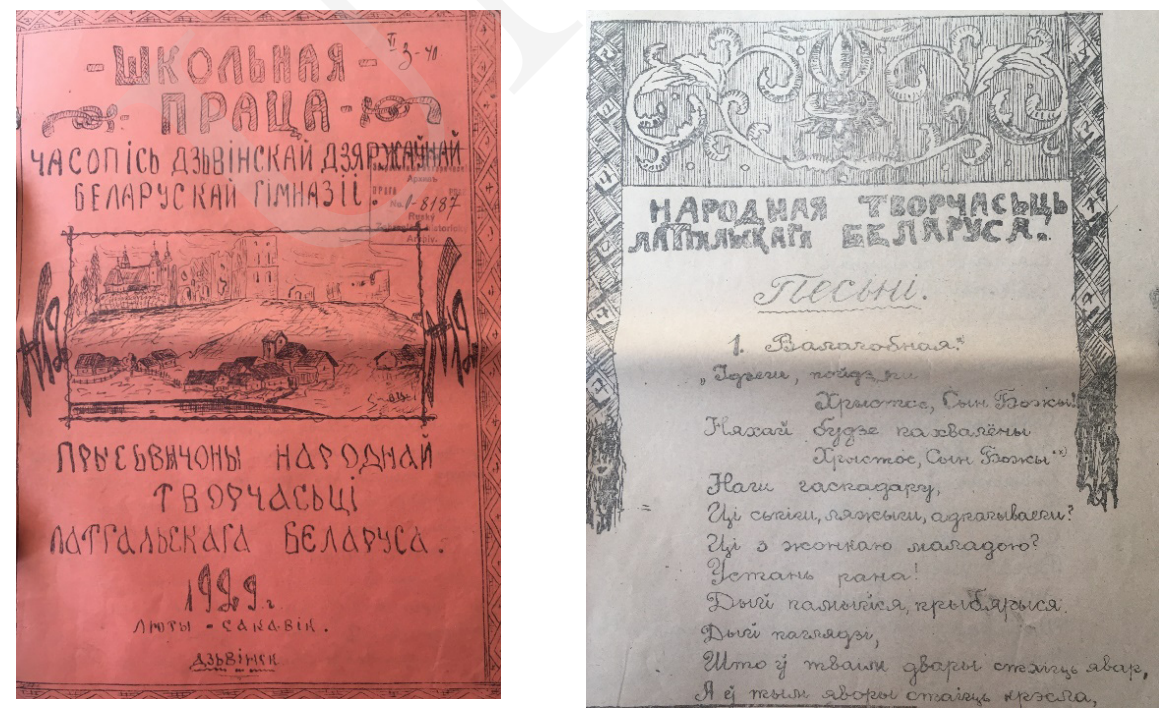

Fot. 5 i 6 . Strona tytułowa „Szkol'nej pracy” oraz strona z twórczością łatgalskich Białorusinów, № 12/1929.

13 Pol. Praca szkolna.

14 Pol. Czasopismo Białoruskiego Państwowego Gimnazjum w Dźwińsku. 


\section{„Беларуская школа ў Латвіi” (1927-1933)}

„Biełaruskaja szkoła ŭ Łatwii” ukazywała się w latach 1927-1933, przy tym najwięcej numerów ukazało się w roku 1932 oraz 1933, kilka - w 1927 natomiast w roku 1928 i 1929 wyszło tylko po jednym numerze. Pełna nazwa brzmiała: „Беларуская школа ў Латвіі. Педагогічна-грамадзкі штомесячнік Т-ва беларускіх вучыцялёу Латвіi”" ${ }^{5}$, redakcja znajdowała się w Rydze przy ul. Alberta 5 m. 9, a redaktorem naczelnym był przewodniczący Towarzystwa Nauczycieli Białoruskich K. Jezawitaŭ. Numer kosztował 50 santimów i początkowo był drukowany w ryskiej typografii Levin, znajdującej się przy ul. Dzirnavu 33, później w drukarni G. Ige przy ul. Gertrūdes 80, a następnie na starym mieście, przy Vecpilsētā 8. Wydawcą było Wydawnictwo Białoruskie (Беларускае Выдавецтва).

Redakcja poruszała tematy dotyczące bieżącej działalności szkół, nauczycieli, Towarzystwa Nauczycieli Białoruskich, działalności białoruskiego Teatru Narodowego w Rydze, bieżących wydarzeń na Łotwie, Litwie, w Polsce, na Ukrainie, w Czechosłowacji i sowieckiej Białorusi. Ponadto zamieszczano najlepsze prace uczniów szkół białoruskich, poezję oraz kronikę. Wśród autorów tekstów można było znaleźć takie osoby, jak: K. Jezawitaŭ, S. Sacharaŭ, A. Bartkiewicz, B. Breżgo, Radnik, K. Adradżeniec, S. Kazeka, T. Pryjazny, A. Palianski czy Kanhresawiec.

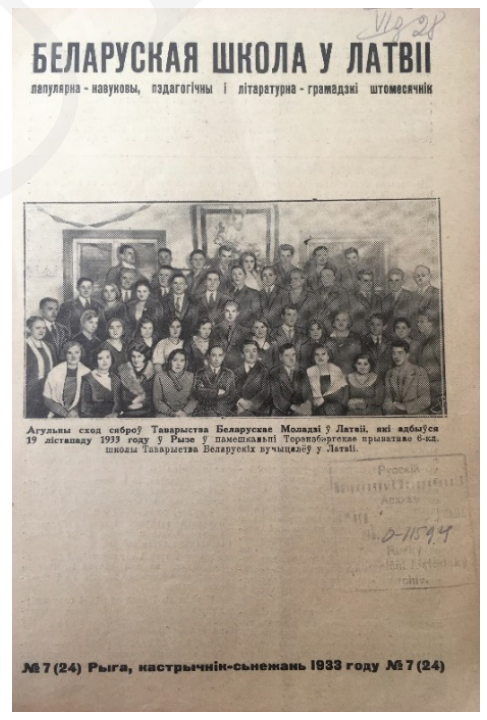

Fot. 7. Strona tytułowa „Biełaruskaj szkoły ŭ Łatwii”, № 7(24)/1933.

15 Pol. „Białoruska szkoła na Łotwie. Pedagogiczno-społeczny miesięcznik Towarzystwa białoruskich nauczycieli Łotwy”. W 1932 i 1933 r. druga część tytułu nosiła nazwę „Папулярнанавуковы, пэдагогічны і літаратурна-грамадзкі штомесячнік” („Miesięcznik popularno-naukowy, pedagogiczny i literacko-społeczny”). 


\section{„Наша Доля” (1930)}

W Bibliotece Narodowej w Rydze zachowały się cztery czterostronicowe numery „Naszej Doli” - pierwszy numer ukazał się 26 stycznia, a czwarty - 7 kwietnia 1930 roku. Był to organ Białoruskiej Myśli Demokratycznej na Łotwie (Орган Беларускай дэмократычнай думкі ў Латвіi), a gazeta wychodziła dwa razy w miesiącu (w języku białoruskim, tzw. taraszkiewicą) i kosztowała 10 santimów. Redakcja znajdowała się w Dyneburgu przy ul. Skrindas 13. Gazeta była drukowana w drukarni miejskiej przy ul. Zielonej 8 (Zą̧ā iela 8). Redaktorem naczelnym był Uładzimir Widaŭski, a wydawcą Białoruskie Towarzystwo Kulturowo-Oświatowe „Praświeta”. Wśród autorów tekstów można było znaleźć takie osoby, jak: Pihuleuski (deputat sejmu), J. Kastyliuk, niektórzy podpisywali się pseudonimami, jak np.: Prysutny 'Obecny', Stary Biełarus 'Stary Białorusin', Prawasłaŭny Biełarus 'Prawosławny Białorusin'.

Tematem nadrzędnym gazety były bieżące wydarzenia polityczne i działalność mniejszości białoruskiej na Łotwie, uzupełnione o nowiny z zagranicy, sprawozdania $\mathrm{z}$ działalności organizacji i kronikę. Ponadto w kolejnych numerach znajdował się dział „Arataja” z poradami praktycznymi dla gospodarstw wiejskich.

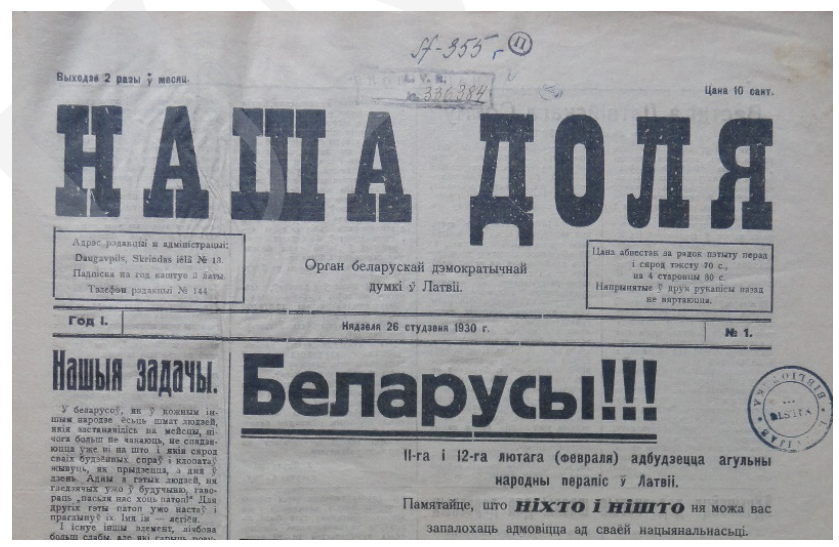

Fot. 8. Fragment tytułowej strony „Naszej Doli”, № 1/1930.

\section{„Шлях праўды” (1930)}

Wychodzący w Rydze „Шлях праўды. Беларуская аднаднёўка”"16 to gazeta planowana jako dziennik. Prawdopodobnie wyszedł tylko jeden numer. Kosztował 10 santimów, redaktorem odpowiedzialnym był F. Klahisz, a wydawcą Dźwiński i Lucynski Oddziały Towarzystwa Nauczycieli Białoruskich na Łotwie (Дзьвінскі і Люцынскі Аддзелы Т-ва Беларускіх вучыцялёў у Латвіi). Gazeta liczyła 4 czarno-białe strony

16 Pol. „Szlak prawdy. Białoruska jednodniówka”. 
i na jej łamach podejmowano bieżące wydarzenia z życia politycznego, społecznego Białorusinów Łotwy.

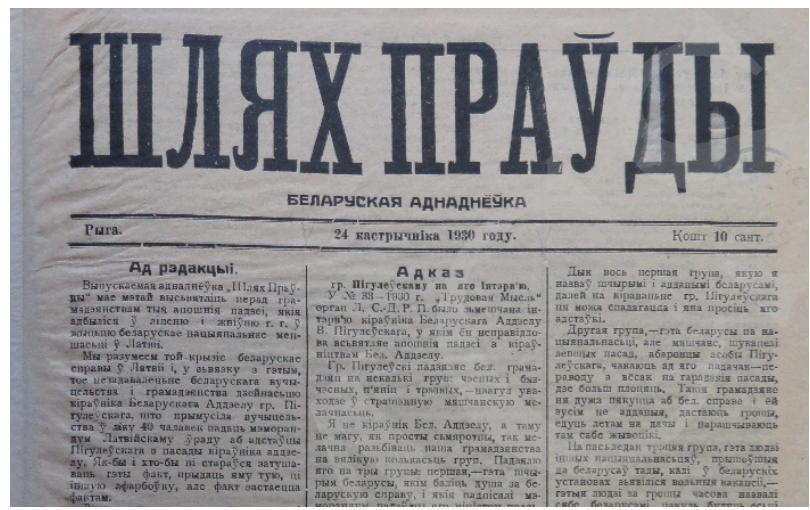

Fot. 9. Fragment strony tytułowej „Szliachu praŭdy”, 24.10.1930.

\section{„Школа і жыццё” (1930)}

Pełna nazwa miesięcznika brzmiała: „Школа і жыццё. Беларускі літэратурнаграмадзкі і педагогічны штомесячнік Таварыства беларускіх вучыцялёў у Латвіi’'17. Autor dysponuje tylko jednym (pierwszym) numerem, wydanym w Rydze w 1930 r. (za styczeń-luty). Jest to obszerne czasopismo, na które składa się cykl rozbudowanych artykułów liczących po kilka lub kilkanaście stron. Czytelnik mógł zapoznać się z sylwetką Jānisa Rainisa (łotewskim pisarzem, politykiem) ${ }^{18}$, zasadami funkcjonowania szkoły, zagadnieniami historycznymi oraz sprawozdaniem z działalności Białoruskiego Towarzystwa Oświatowego „Białoruska chata”.

Czasopismo zostało wydrukowane w drukarni przy ul. Ģertrūdes 80 , a redakcja znajdowała się w Rydze przy ul. Tumes 2. Redaktorem naczelnym był. M. Dziamidaŭ ${ }^{19}$.

17 Pol. „Szkoła i życie. Białoruski literacko-społeczny miesięcznik pedagogiczny Towarzystwa nauczycieli białoruskich Łotwy".

18 Więcej o jego działalności w kontekście mniejszości białoruskiej na Łotwie zob. (Korolëv, 2016, s. 54-56).

19 Więcej o działalności Mikałaja Dziamidawa na Łotwie zob. (Gryboǔskì, 2016). 


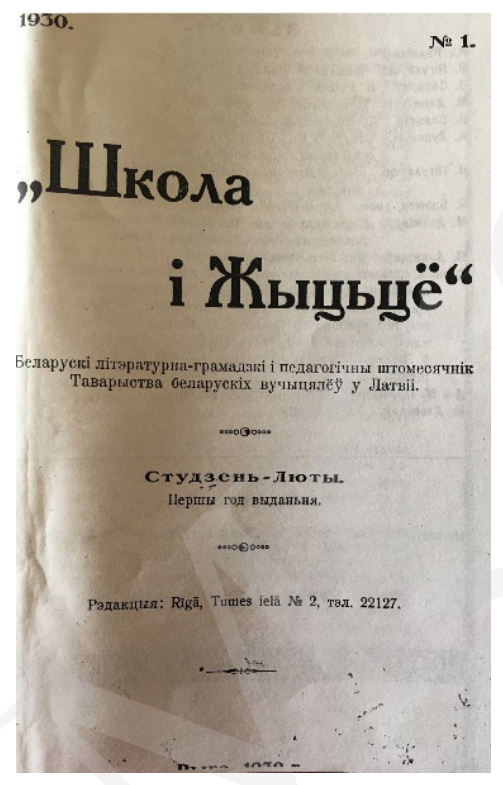

Fot. 10. Czarno-biały skan pierwszej strony miesięcznika „Szkoła i żyćcio”, № 1/1930.

\section{„Пагоня” (1930)}

Zachował się tylko jeden, pierwszy numer „Pahonii” (№ 1/1930), czasopisma będącego organem Towarzystwa Białoruskiej Młodzieży na Łotwie (Ворган Таварыства Беларускае Моладзі ў Латвіi). Pełna nazwa brzmiała: „Пагоня. Беларускі Грамадзка-навукова-літэратурны журнал”20. Redaktorem naczelnym była N. U. Pinskaja, a czasopismo było wydawane przez Towarzystwo Młodzieży Białoruskiej na Łotwie. Wszystkie artykuły (zapisane na maszynie do pisania) były po białorusku (tzw. taraszkiewicą).

Wśród artykułów znajdziemy zagadnienia związane z Białorusinami Łotwy, zwrot do białoruskiej młodzieży, artykuł o organizacyjnych, instytucjonalnych i finansowych brakach w szkołach białoruskich, opis życia i działalności Iwana Łuckiewicza, poza tym opowiadanie ludowe, zapisane w wiosce powiatu lucyńskiego, pieśni ludowe, wiersze oraz kronikę. Wśród autorów znaleźli się: W. Żurkoŭski, W. Walter, J. Kastyliuk oraz Turaŭszczanka.

\footnotetext{
20 Pol. „Pogoń. Białoruskie czasopismo społeczno-naukowo-literackie”.
} 


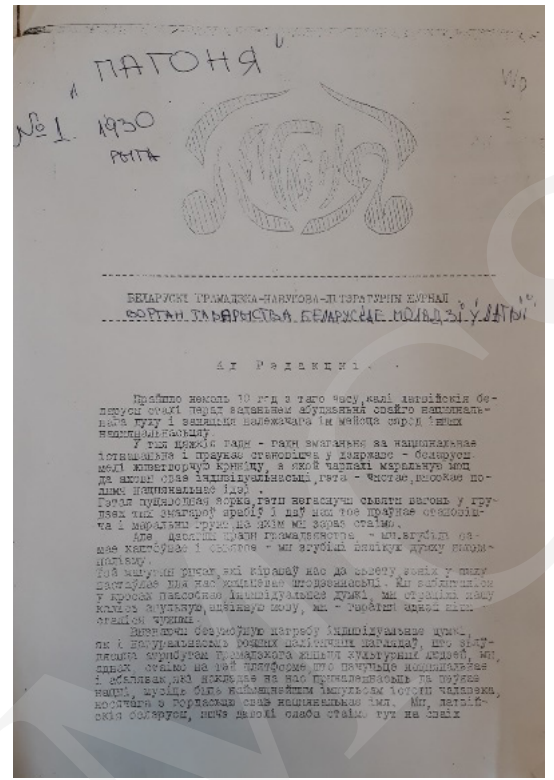

Fot 11. Strona tytułowa czasopisma „Pahonia”, № 1/1930.

\section{„Думка Беларуса” (1931-1931)}

W Bibliotece Narodowej w Rydze zachowało się 5 numerów „Dumki Biełarusa”, która była czasopismem wydawanym po białorusku ${ }^{21}$ przez Białoruską Partię Demokratyczną na Łotwie (Беларуская дэмакратычная Партыя ў Латвіi). Pełna nazwa brzmiała: „Думка Беларуса. Часопіс Беларускае Дэмакратычнае партыі ў Латвіi”. Redakcja znajdowała się w Dyneburgu przy ul. Wileńskiej 23 m. 5 (Vilņas iela 23/5). Redaktorem był J. Jakuboŭski, wydawcą Białoruska Partia Demokratyczna na Łotwie. Cena gazety wynosiła 12 santimów. Drukowana była w drukarni miejskiej przy ul. Zielonej 8 (Zaḷā iela 8).

$\mathrm{Na} ł a m a c h$ gazety poruszane były tematy społeczno-polityczne, bieżące wydarzenia w regionie dotyczące Białorusinów, czy kwestia polonizacji w Iłukszcie, a wśród autorów tekstów byli: Dziemienski, Z. M-wicz, M.T., S. Sacharaŭ. Pisano też pod pseudonimem: Pustynianin 'mieszkaniec gminy Pustynia', Chutaranin 'mieszkaniec chutoru', czy Biełaruski Wuczyciel' 'Białoruski Nauczyciel'.

${ }_{21}$ Kilka krótkich tekstów jest po rosyjsku, ale gazeta ma zdecydowanie charakter białoruskojęzyczny. 


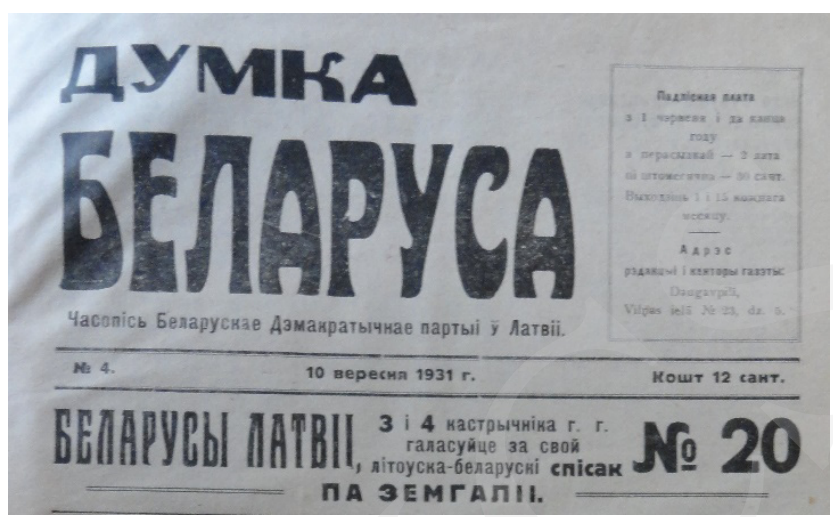

Fot. 12. Fragment strony tytułowej „,Dumki Biełarusa”, № 4/1931.

\section{„Беларускае слова” (1931)}

Była to gazeta poświęcona sprawom Białorusinów na Łotwie, opisująca również bieżące wydarzenia polityczne, społeczne, nowinki z życia Białorusinów na Litwie, w Polsce, ZSRR, Czechosłowacji. Redaktorem-wydawcą był P. Żurkoŭski, a siedziba redakcja znajdowała się w Rydze przy ul. Nometņu 33. Wśród autorów znajdowali się: P. Żurkoŭski, ks. A. Pastor, Mużyczok. Zachowały się tylko dwa numery gazety z roku 1931 (z 10.08 i 25.09.). Artykuły były pisane po białorusku (tzw. taraszkiewica).

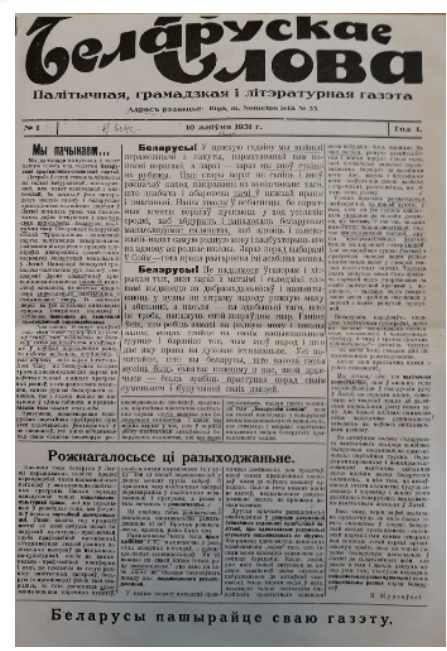

Fot. 13. Strona tytułowa gazety „Biełaruskaje słowa”, № 1/1931. 


\section{Podsumowanie}

Powyżej została scharakteryzowana prasa białoruska wychodząca na Łotwie w okresie międzywojennym. Poza omówionymi tytułami w okresie okupacji niemieckiej, tj. w latach 1942-1944, w Rydze wychodził białoruski „Nowy szliach” („Новы шлях”), a wcześniej także „Biełaruski kaliandar” (autor dysponuje dwoma numerami, za 1928 i 1937 rok). Innego typu publikacje, w tym książkowe, nie zostały omówione w niniejszym artykule.

Przegląd ówczesnej prasy ukazuje nam szereg aspektów. Z 12 dostępnych autorowi periodyków większość ukazała się tylko w jednym lub kilku numerach („Na Czużynie”, „Haspadar”, „Nasza dolia”, „Szliach praŭdy”, „Szkoła i żyćcio”, „Pahonia”, „Dumka biełarusa” i „Biełaruskaje słowa”). Z jednej strony wskazywało to na duże chęci białoruskich działaczy do tworzenia mediów białoruskojęzycznych, informujących swoich rodaków o bieżących wydarzeniach, życiu czy edukacji, a z drugiej strony, zapewne, o dużych problemach organizacyjno-finansowych. Niejednokrotnie redakcje zwracały się z prośbą lub zachęcały do prenumerowania ich gazety i finansowego wsparcia. Większe znaczenie odegrały w zasadzie trzy tytuły: „Hołas biełarusa” (wyszło 61 numerów), „Biełaruskaja szkoła ŭ Łatwii” (24 numery) oraz „Szkol’naja praca" (13 numerów). Były one redagowane przez K. Jezawitawa i S. Sacharawa, czyli dwóch bardzo aktywnych białoruskich działaczy na Łotwie tamtego okresu, za którymi dodatkowo stały konkretne organizacje.

Należy podkreślić, że białoruska prasa często wychodziła nieregularnie, okres świetności „Hołasa biełarusa” przypada na lata 1925-1927, „Biełaruskiej szkoły ŭ Łatwii” na lata 1932-33 i częściowo 1927, „Szkolnej pracy” na 1926 rok. Zauważalne jest mocne załamanie prasy białoruskiej w latach 1928 i 1929 wynikające bardziej z aktywności mniejszości białoruskiej (spraw organizacyjnych i finansowych) niż polityki władz łotewskich wobec mniejszości narodowych. Znaczącą część łotewskich Białorusinów, a zarazem potencjalnych czytelników-prenumeratorów, stanowiła ludność wiejska, co nie pozostawało bez wpływu na proces wydawniczy prasy. Prasa białoruska przestała wychodzić w roku 1933, tj. przed wprowadzeniem przez K. Ulmanisa rządów autorytarnych (charakteryzujących się m.in. lettyzacją kraju i dużym ograniczaniem autonomii mniejszości narodowych). Oznacza to, że powodem zapaści ówczesnych mediów białoruskich były bardziej problemy organizacyjno-finansowe niż polityka władz łotewskich.

Gazety były ukierunkowane na różne grupy społeczne i podejmowano na ich łamach zróżnicowaną tematykę - od bieżacych spraw politycznych i życia Białorusinów na Łotwie („Hołas biełarusa”, „Nasza dolia”, „Szliach praudy”, „Dumka biełarusa” i „Biełaruskaje słowa”), sprawy białoruskiego szkolnictwa (,Szkol'naja praca”, „Biełaruskaja szkoła ŭ Łatwii”) czy sprawy związane z pracami polowymi (Haspadar).

Najwięcej gazet wychodziło w Rydze („Na Czużynie”, „Hołas biełarusa”, „Haspadar”, „Biełaruskaja szkoła ŭ Łatwii”, „Szliach praŭdy”, „Szkoła i żyćcio”, „Pahonia” i „Biełaruskaje słowa”), dwie - w Dyneburgu: „Szkol'naja praca” i „Nasza dolia”, 
a w Lucyniu - jedynie „Lastaŭka”. Wszystkie artykuły w wyżej wymienionych tytułach wydawane były cyrylicą po białorusku (z wyjątkiem kilku tekstów po rosyjsku), zapisywane tzw. taraszkiewicą (reforma języka miała miejsce dopiero w 1933, kiedy już nie wychodziła prasa białoruska na Łotwie).

Choć pod względem aktywności trudno jest porównywać działalność łotewskich Białorusinów do Polaków ${ }^{22}$ czy Rosjan, to należy podkreślić ich dużą aktywność społeczno-kulturalną, która odnosiła się tak do prasy, jak i innych aspektów życia tej mniejszości narodowej. Prasa wychodząca w okresie międzywojennym niewątpliwie miała ogromne znaczenie na kształtowanie świadomości narodowej Białorusinów Łotwy. Za jej pośrednictwem nie tylko informowano rodaków o bieżących wydarzeniach politycznych, społecznych i edukacyjnych, ale również świadomie formowano poczucie białoruskości, przede wszystkim w oparciu o opozycję wobec tamtejszych Polaków i Rosjan. Jest to bardzo dobrze widoczne na przykładzie szeregu tekstów zamieszczanych na łamach omawianej prasy. Takie postępowanie redaktorów i autorów było zrozumiałe w kontekście ówczesnej sytuacji polityczno-społecznej na Łotwie. O ile obecność Białorusinów na ziemiach łotewskich sięga dawniejszych czasów, to początki kształtowania się białoruskiej inteligencji, tożsamości oraz działalności społeczno-kulturalnej należy wiązać dopiero z datą rewolucji 1905 r. Pomimo licznych problemów logistycznych (brak elit, kadr - chociażby nauczycieli), finansowych i politycznych należy jednak podkreślić ogrom pracy i wysiłku włożony przez białoruskich działaczy społeczno-kulturalno-politycznych w utworzenie białoruskiego szkolnictwa i prasy na Lotwie okresu międzywojennego.

Tab. 1. Spis białoruskiej prasy wydawanej na Łotwie w okresie międzywojennym wykorzystanych przez autora.

\begin{tabular}{|l|l|l|}
\hline Nazwa / charakter & Lata i miejsce wydania & Numery \\
\hline „На чужыне” & 1920, Ryga & 1 \\
\hline „Ластаўка” & 1923, Lucyn & 1 \\
\hline „Голас беларуса” & 1925-1929, Ryga & $1925: 1-7,10,11,12,13,16,17,18$ \\
& & $1926: 1(19)-29(47)$ \\
& & $1927: 1(48)-11(58)$ \\
& & $1928: 1(59)$ \\
& & $1929: 1(60) ; 2(61)$ \\
\hline „Гаспадар” & 1926, Ryga & $1-4$ \\
\hline „Школьная праца” & 1926-1929, Daugavpils & $1926: 2,3,4,5,6$ \\
& & $1927: 7,8,9$ \\
& & $1928: 10$ \\
& & $1929: 12,13$ \\
\hline
\end{tabular}

22 Zob. np. rozprawę doktorską Ivety Ruckiej (Rucka, 2008). 
Pobrane z czasopisma Studia Bia?orutenistyczne http://bialorutenistyka.umcs.pl Data: 26/04/2023 11:17:47

Prasa białoruska międzywojennej Łotwy (przegląd wydawnictw)

\begin{tabular}{|c|c|c|}
\hline $\begin{array}{l}\text { „Беларуская школа ў } \\
\text { Латвіi” }\end{array}$ & 1927-1933, Ryga & $\begin{array}{ll}1927: & 3(1) ; 4(2) ; 5(3) ; 6(4) ; 7(5) \\
1928: & 8(1) \\
1929: & 9(1) \\
1932: & 1(11) ; 2(12) ; 3(13) ; 4(14) ; \\
& 5(15) ; 6(16) ; 7(17) \\
1933: & 1(18) ; 2(19) ; 3(20) ; 4(21) ; \\
& 5(22) ; 6(23) ; 7(24)\end{array}$ \\
\hline „Наша Доля” & 1930, Daugavpils & $1-4$ \\
\hline „Шлях праўды” & 1930, Ryga & 24.10 .1930 \\
\hline „Школа і жыццё” & 1930, Ryga & 1 \\
\hline „Пагоня” & 1931, Ryga & 1 \\
\hline „Думка Беларуса” & 1931, Daugavpils & $1-5$ \\
\hline „Беларускае слова” & 1931, Ryga & $1-2$ \\
\hline
\end{tabular}

\section{REFERENCES / BIBLIOGRAFIA}

Ageenka, Taccâna. (2017). Vydaveckaâ ì ètnagrafî̌naâ dzejnasc' belarusaǔ u Latvì̀ ǔ 1920 1030-â gg., Latyšu u belorusy vmeste skvoz' veka, wyp. 6 (s. 38-41). Vitebsk. [Агеенка, Таццяна. (2017). Выдавецкая і этнаграфічная дзейнасць беларусаў у Латвіі ў 19201030-я гг, Латыши и белорусы вместе сквозь века, вып. 6 (с. 38-41). Витебск].

Apine, Ilga. (1995). Baltkrievi Latvijā. Rīga: Latvijas Zinātņu akadēmija.

Apine, Ilga. (2017). Baltkrievu etnoss latvju zemē (līdz 1941). Priekšvēsture, pētījumi, pirmais padomju gads. W: Hermanis Voldemārs (red.). Saprast Baltkrieviju (s. 30-38). Rīga: Zelta grauds.

Barszczewska, Nìna. (2004). Belaruskẩ èmìgracyâa - abaronca rodnae movy. Varšava: Katèdra Belaruskaj Fìlâlëgì̀. [Баршчэўская, Ніна. (2004). Беларуская эміграцыя - абаронца роднае мовы. Варшава: Катэдра Беларускай Філялёгіi].

Cīrule, Astrīda. (2017). Rainis un baltkrievi. No bērnības līdz ministra krēslam. W: Hermanis Voldemārs (red.), Saprast Baltkrieviju (s. 39-47). Rīga: Apgāds Zelta grauds.

Gabranova, Ûliâ. (2014). Periodičeskie izdaniâ na belorusskom âzyke, izdannye v period Pervoj Latvijskoj Respubliki (1920-1930). Russkaâ fililogiâ. Sbornik naučnyh rabot molodyh filologov. Tartu: Tartuskij universitet. [Габранова, Юлия. (2014). Периодические издания на белорусском языке, изданные в период Первой Латвийской Республики (1920-1930). Русская филилогия. Сборник научных работ молодых филологов. Тарту: Тартуский университет].

Gabranowa, Jūlija. (2016a). Baltkrievu un latviešu valodas kontakti 20. gadsimta pirmajā pusē in mūsdnienās. Promocijas darba kopsavilkums. Liepāja: Liepājas Universitāte. [rozprawa doktorska].

Gabranowa, Jūlija. (2016b). Baltkrievu un latviešu valodas kontakti 20. gadsimta pirmajā pusē in mūsdnienās. Promocijas darba kopsavilkums. Liepāja: Liepājas Universitāte. [streszczenie rozprawy doktorskiej]. 
Golubeva, Natallâ (red.). (2010). Belaruskae zamežža. Mìnsk: Belaruskaâ èncyklapedyâ ìmâ Petrusâ Broǔkì. [Голубева, Наталля (рэд.). (2010). Беларускае замежжа. Мінск: Беларуская энцыклапедыя імя Петруся Броўкі].

Hermanis, Voldemārs (red.). (2017). Saprast baltkrieviju. Rīga: Apgāds Zelta grauds.

Gryboǔskì, Ûry; Ekabsons, Ėriks. (2013). Kastus' Ezavìtaǔ ì âgony «bèrlìnskì» dzën'nìk. Zapisy, 36, s. 216-233. [Грыбоўскі, Юры; Екабсонс, Эрикс. (2013). Кастусь Езавітаў і ягоны «бэрлінскі» дзёньнік. Зanicbl, 36, с. 216-233].

Grybowski, Jerzy. (2015). Saveckaâ rèčaìsnasc' na bačynah belaruskaj gazety ǔ Latvì̀ „Golas Belarusa” (1925-1929 g.). [Савецкая рэчаіснасць на бачынах беларускай газеты ў Латвіi „Голас Беларуса” (1925-1929 г.)]. W: Marta Kaczmarczyk, Albert Nowacki, Monika Sidor, Beata Siwek (red.). , Światta masz tyle w sobie...”. Ze studiów wschodniostowiańskich. Księga pamiątkowa dedykowana Profesorowi Aleksandrowi Barszczewskiemu w osiemdziesiąta piąta rocznicę urodzin (s. 207-222). Lublin: Wydawnictwo KUL].

Gryboǔskì, Ûry. (2016). «Latvìjskì» peryâd dzejnascì Mìkalaâ Dzâmìdava (1922-1942). Belaruski gistaryčny aglâd, 23, s. 41-71. [Грыбоўскі, Юры. (2016). «Латвійскі» перыяд дзейнасці Мікалая Дзямідава (1922-1942). Беларускі гістарычны агляд, 23, с. 41-71].

Jankowiak, Mirosław. (2019). Farmavanne ìdèntyčnascì belarusaǔ Latvì̀. W: Vital. Makarèvìč ed.), Belarus' u èpohu geapalityčnyh ì sacyâl'nyh zruhaǔ novaga ì navejšaga času (s. 8589). Mìnsk. [Янковяк, Міраслаў. (2019). Фармаванне ідэнтычнасці беларусаў Латвіi, В: Віталь Макарэвіч (рэд.). Беларусь у эпоху геапалітычных $і$ сацыяльных зрухау новага і навейшага часу (с. 85-89). Мінск].

Jankowiak, Mirosław. (2009). Białorusini Łatgalii - autochtoni czy imigranci? Acta Albaruthenica, 8, s. 264-274.

Jekabsons, Èriks. (2004). Kul'turnaâ deâtel'nost' belorusov Latvii v 1918-1940 godah. W: Latviâ - Belarus': dyâlog dvuh kul'tur. Ì mìžnarodny navukova-praktyčnaâ kanferèncyâ (s. 76-90). Mìnsk. [Екабсонс, Эрикс. (2004). Культурная деятельность белорусов Латвии в 1918-1940 годах. В: Латвія - Беларусь: дыялог двух культур. Іміжнароднь навукова-практычная канферэнцыл (с. 76-90). Мінск].

Jekabsons, Èriks. (2017). Politika Latvijskogo gosudarstva v otnošenii belorusov. W: Maksim Korolëv (red.), Latviâ - Belarus' 1918-2018 (s. 122-143). Minsk: Četyre četverti. [Екабсонс, Эрикс. (2017). Политика Латвийского государства в отношении белорусов. В: Максим Королёв (ред.), Латвия - Беларусь 1918-2018 (с. 122-143). Минск: Четыре четверти].

Kazačënok Katryna. (2012). «Belorusskij process» v Latvii: obvinenie, opravdanie, nakazanie. Latyši i belorusy: vmeste skovz' veka, 1, s. 29-43. [Казачёнок Катрына. (2012). «Белорусский процесс» в Латвии: обвинение, оправдание, наказание. Латышии и белорусы: вместе сковзь века, 1, с. 29-43].

Kazačënok, Katryna. (2019). Ezovitov Konstantin Borisovič, W: Maksim Korolëv (red.). Belorusskij sled v Latvijskoj istorii. Biografičeskij spravočnik (s. 31-36). Mink: RIVŠ. [Казачёнок Катрына. (2019). Езовитов Константин Борисович. В: Максим Королёв (общ. ред.). Белорусский след в Латвийской истории. Биографический справочник (с. 31-36). Минк: РИВШ]. 
Korolëv, Maksim. (2016). Rajnis Ânis. W: Maksim Korolëv (red.). Latyši v belorusskoj istorii. Biografičeskij spravočnik (s. 54-56). Minsk: RIVŠ. [Королёв, Максим. (2016). Райнис Янис. В: Максим Королёв (ред.). Латыши в белорусской истории. Биографический справочник (с. 54-56). Минск: РИВШ].

Korolëv, Maksim (red.). (2017). Latviâ - Belarus' 1918-2018. Minsk: Četyre četverti. [Максим, Королёв (ред.). (2017). Латвия - Беларусь 1918-2018. Минск: Четыре четверти].

Rucka, Iveta. (2008). Język polskiej mniejszości narodowej na Łotwie w okresie międzywojennym na materiale prasy $i$ innych druków informacyjnych. Warszawa: Instytut Slawistyki PAN. (Rozprawa doktorska).

Treijs, Rihards (red.). (1996). Latvijas republikas prese 1918-1940. Rīga: Zvaigzne ABC.

SUBMITTED: 25.08 .2020

ACCEPTED: 26.05.2021

PUBLISHED ONLINE: 12.12 .2021

\section{ABOUT THE AUTHOR / O AUTORZE}

Mirosław Jankowiak - Czechy, Praga, Instytut Słowiański Akademii Nauk Republiki Czeskiej, Zakład Językoznawstwa Słowiańskiego i Leksykografii; dr; spec.: językoznawstwo białoruskie; zainteresowania naukowe: język białoruski, dialektologia białoruska, polszczyzna północnokresowa, Białorusini w państwach bałtyckich (język, historia, tożsamość narodowa).

Adres: Slovanský ústav Akademie věd České republiky, Valentinská 1, 11000 Praha 1, Česká republika

Wybrane publikacje:

1. Jankowiak, Mirosław; Vašíček, Michal. (ed.). Slovanské dialekty v jazykovém kontaktu. Nářečni lexikum $v$ pomeznich oblastech $v$ minulosti a současnosti. (2020). Praha: Slovanský ústav Akademie věd ČR.

2. Jankowiak, Mirosław. (2018). Współczesne gwary białoruskie na Łotwie. Charakterystyka. Wybór tekstów. Praha: Slovanský ústav Akademie věd České republiky.

3. Курцова, Вераніка; Снігірова, Наталля; Jankowiak, Mirosław; Ostrówka, Małgorzata. (рэд.). Беларуска-польскія культурна-моўныя ўзаемадачыненні / Białorusko-polskie stosunki kulturowo-językowe. Historia i współczesność. (2016). Мінск.

4. Barszczewska, Nina; Jankowiak, Mirosław. (2012). Dialektologia białoruska. Warszawa: Slawistyczny Ośrodek Wydawniczy.

5. Jankowiak, Mirosław. (2009). Gwary białoruskie na Łotwie w rejonie krasławskim. Studium socjolingwistyczne. Warszawa: Instytut Slawistyki PAN. 